\title{
HYDROPONIC TRAINING AS AN ALTERNATIVE URBAN FARMING
}

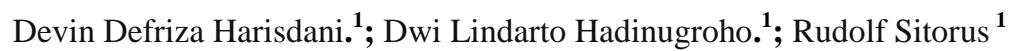 \\ ${ }^{1}$ Department of Architecture, Faculty of Engineering, Universitas Sumatera Utara, 20122 \\ *E-mail: devin.defriza@usu.ac.id - dwi.lindarto@usu.ac.id
}

\begin{abstract}
One of the basic capital in a neighborhood community are schools and mosques. Both communities as actors of development potentially accelerate the pace of urban green space. Community Service Team Faculty of Engineering, Universitas Sumatera Utara introduce hydroponic cultivation of vegetables along with the school partners, MIS Al Falah and Masjid Al Falah Youth Community in Kelurahan Tanjung Rejo, Medan. With the aim of transferring knowledge and skills to improve the ability of community partners in the city implemented a training program with a simulation and practice methods of making the hydroponic systems. Training results showed an increase interest, insight knowledge, insight into the potential of the home yard as part of urban green space, vegetable science insights and increased revenue opportunities with the hydroponic system. The simulation results that the practice of making hydroponic provides improved skill mastery hydroponic model manufacturing process, increased interest in carpentry for manufacturing variations hydroponic models conform to the shape of home yard, as well as increasing interest in the manufacture of advanced hydroponic systems equipped with the manufacture of small-scale green house. The use of hydroponic is most appropriate for urban settlements to improve urban green space and promote alternative urban farming for increase economic revenue.
\end{abstract}

\section{Keywords : Hydroponic, Urban Green Space, Urban Farming, Economic Revenue}

\section{INTRODUCTION}

Changes in land use in dynamically developing city by the determination of various modifiers, include micro environmental factors in the form of a simple conversion of urban green land use into residential use or other undeveloped land [1]. It thereby triggers city problems in the provision of urban green space. Wooded area converted into a commercial area, residential, industrial, transportation networks and any other city facilities. Urban environment develop economically but ecologically decreased so that the balance of the urban ecosystem is disturbed, which is characterized among other things by rising temperatures and air pollution, declining soil surface and increasing the danger of flooding. In the long term, this condition will cause a decrease in the productivity of economic activities and impair quality of life in urban areas [2]. Urban fabrics tends to minimize green open space. Green open space (Ruang Terbuka Hijau; RTH) is a public urban green space owned and managed by local government city used for the benefit of society in general [3]. RTH types are included in a public green space, among others like city parks. 
Harisdani, DD. et al. Hydroponic Training As An Alternative Urban Farming.

As part of the city, city parks are affected by the current development. The existence of this city parks essentially very important. Carrying capacity of the city is not only supported by the city's ability to provide physical care but also nature's ability to maintain the health of the city [4].

One effort that can be done in limited city parks as a part of urban green space by maximizing the use of existing open space. Using hydroponic system can be use for support urban green space by utilizing hydro / water as land for farming [5].

The same condition also occurs in Medan, North Sumatra Province, Indonesia. Medan city as one of the largest cities in Indonesia also experienced a fairly rapid development which led to the reduction of urban open space that can be used as a city park.

With the partnership with the MIS Al Falah school and Youth Community Group of Masjid Al-Falah in Kelurahan Tanjung Rejo Medan, Community Service Team in Faculty of Engineering, Universitas Sumatera Utara attempted to introduce hydroponic system as one of the growing medium to support the utilization of existing open space being part of city parks, as urban green space in the city of Medan.

\section{METHOD OF ACTIVITY}

\section{Situation Analysis}

One subdistrict of Medan populous is the district of Kecamatan Medan Sunggal with 1544 ha area and a 110,000 population[6].

The population is thus very significant to the city land cover due to the growth of settlements. Kelurahan Tanjung Rejo in Kecamatan Medan Sunggal with 300 ha and
4800 population is located in the border region of dense settlements of traditional and structured settlements named Taman Setiabudi Indah Real Estate (Fig.1).
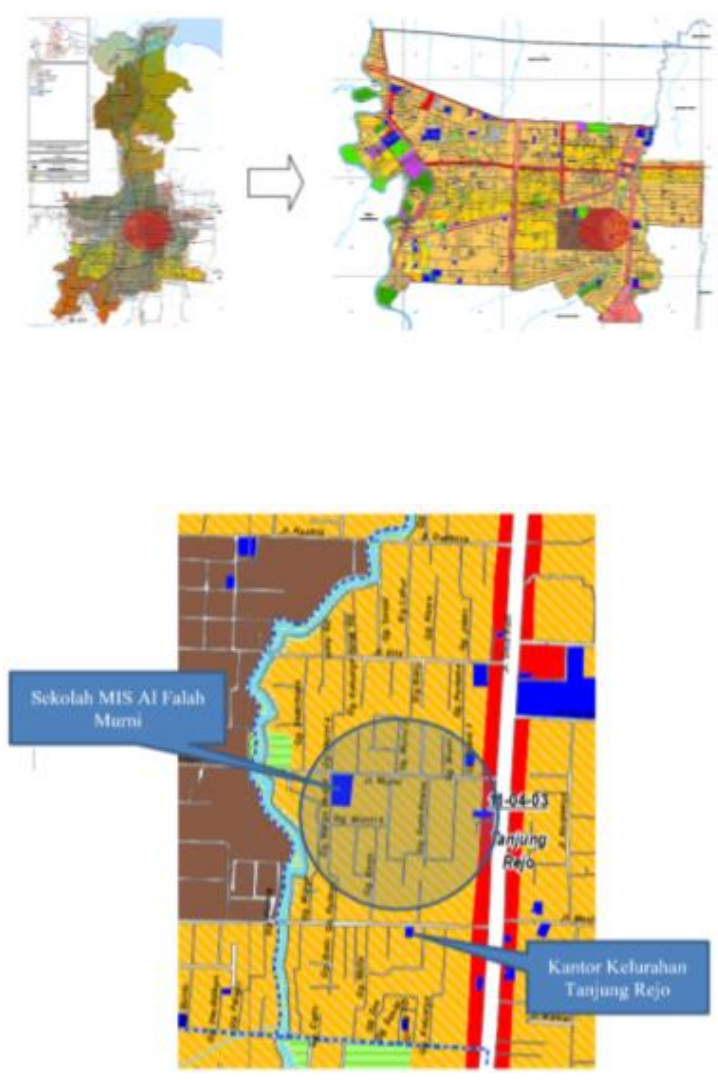

Figure 1. Location of Kelurahan Tanjung Rejo, Medan.

In this region there are nine settlement area that $80 \%$ utilization of developed land makes the lack of urban green open space by the pattern of behavior of people in covering their home yards.

Urban open space problems in Kelurahan Tanjung Rejo is in addition to the lack of green open space, not well-organized urban landscape plants, lack of effective management of greening and lower community participation 
in managing green open space in the neighborhoods (Fig.2).

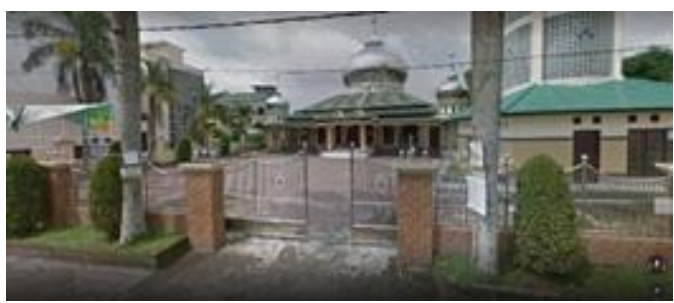

Figure 2.Existing urban open space condition in Kelurahan Tanjung Rejo

Community participation as social capital is a social resource that can be seen as an investment to obtain new resources in the community. Therefore, social capital is believed to be one of the main components in moving together, the mobility of ideas, mutual trust and mutual benefit to achieve common progress. Social capital plays a very important to the functioning and strengthening of modern public life, including in the management of the urban greenery and urban open space. Various problems and irregularities that occurred in the construction of urban fabrics due to low social capital that grows in the community. Countermeasures urban green problems in Kelurahan Tanjung Rejo thus can be approximated by strengthening the social capital of community participation [7][8].

Under the background of inequality in urban green procurement in Kelurahan Tanjung Rejo, coordination efforts are needed to increase community participation. Strengthening social capital by three parameters of social capital trust, norms, networks, an act of community service to be performed by scholars in Department of Architecture, Universitas Sumatera Utara with MIS Al Falah school teachers and Masjid Al Falah youth, Kelurahan Tanjung Rejo in hopes of becoming the triggers of science for the public and MIS Al Falah school students.

The analysis carried out in several stages:

\section{Observation}

Starting with doing interviews and site surveys to partners, namely the MIS Al Falah school and Masjid Al Falah youth comunity. From the results of these observations obtained basic data regarding the condition of the existing school and yard as the utilization of urban green space.

Identification to determine the potential of yard to be used as a means of urban green space, education means the introduction of various kinds of ornamental plants and herb, outdoor play area, social activities, and to explore creativity [9].

\section{Training}

After the approval of partners signing a statement of willingness to cooperate, and then the team of community service make some technical guide about hydroponic system based PVC pipe fitted with the format of an evaluation of the urban green program for as feedback for continuous improvement and obtain data inputs successful community service programs that do.

After getting the technical guidelines, then held a training training jointly by MIS teachers, parents and students, also Masjid Al Falah youth comunity. In the direct training guided by the team of community service in Department of Architecture, Universitas Sumatera Utara, participants can directly interact and ask the things that are considered less evident in the technical guide.

Props supporting training activities include: technical guides and posters that contain a persuasive invitation to city parks as part of urban green space with the hydroponic system(Fig.3). 

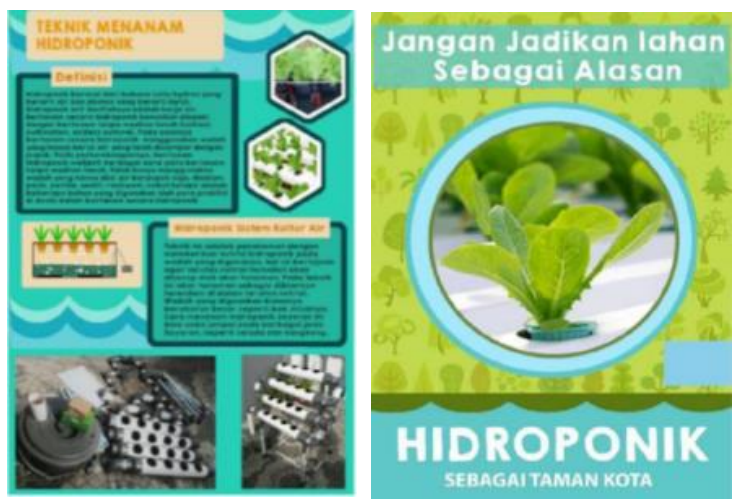

Figure 3. Hydroponic System Posters

\section{Simulation}

Simulations carried out in 3 stages:

a. The division of labour groups

After the explanation of the audio and video training guide, the participants were divided into 10 (ten) groups with each group consisting of 5 (five) persons. Each of these groups will be guided by a tutor for the assembly of hydroponic appropriate technical guidelines.

b. Simulation of hydroponic system

With introduction of tools, measuring and cutting PVC pipe into a pipe assembly stage hydroponic and hydroponic function test(Fig.4,5,6,7).

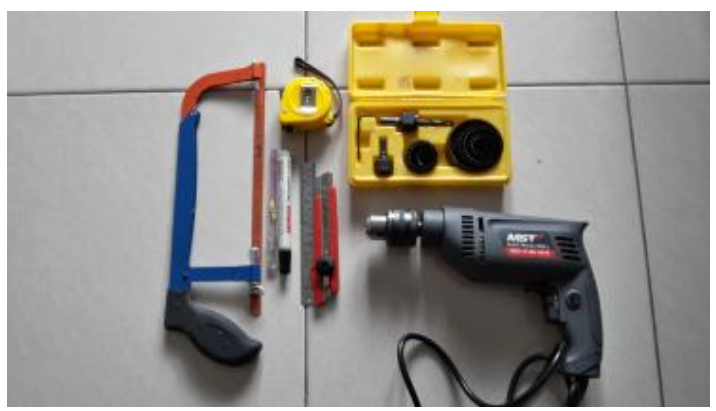

Figure 4. Equipment and tools for cutting PVC Pipe in hydroponic system

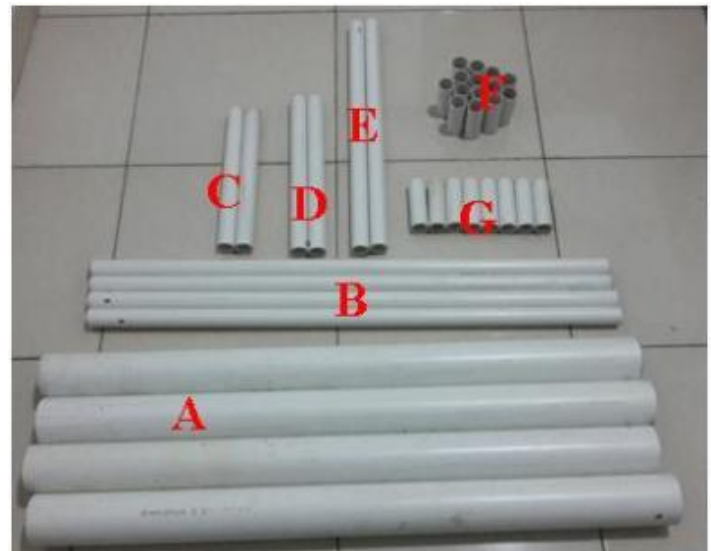

Figure 5. PVC Pipe in hydroponic system

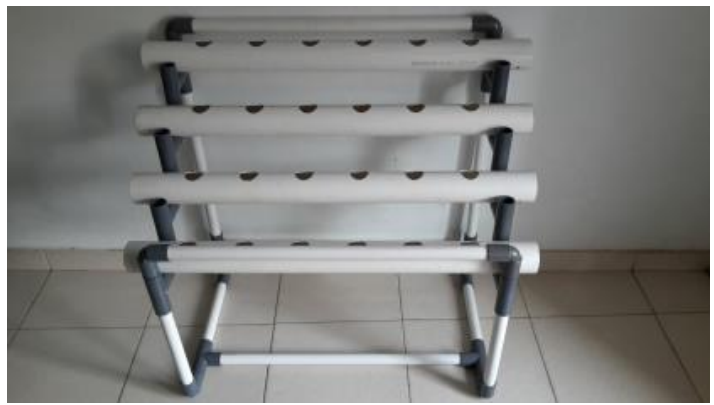

Figure 6. Assembling the hydroponic framing

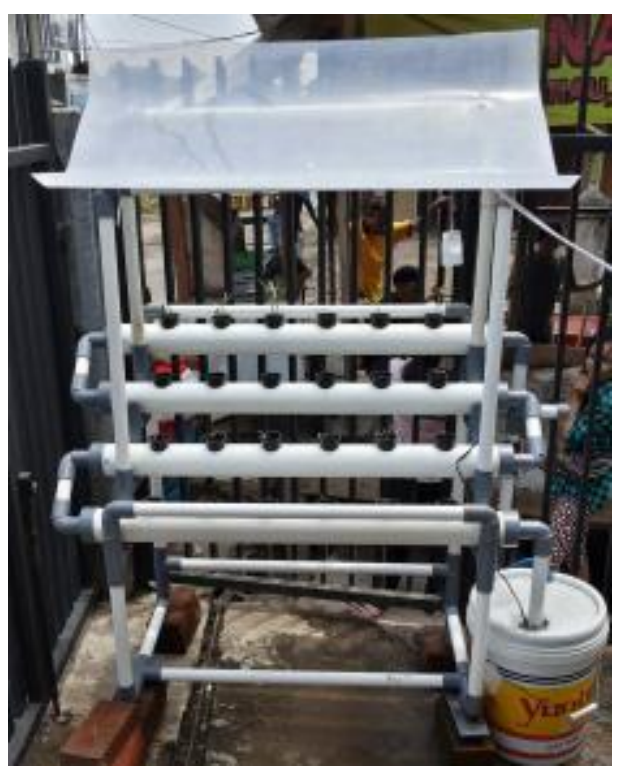

Figure 7. Test the function of hydroponic system 
Harisdani, DD. et al. Hydroponic Training As An Alternative Urban Farming.

c. Installation of labels on any type of crop

After making a complete hydroponic system and plants are placed in containers PVC, then the labeling that indicates the name of the hydroponic plants. This activity is to provide education on the types of crops that can be planted use this PVC hydroponic system.

\section{RESULT AND DISCUSION}

Distribution of the questionnaire were undertaken to gather data on the training and simulation with this hydroponic system produces information that $88 \%$ of participants claimed to have increased insight into their hydroponic systems to improve urban green space and promote alternative urban farming. This training has also been growing interest in gardening who felt enthusiastic by $70 \%$ of participants. Increased creativity in hydroponic gardening techniques expressed by $65 \%$ of participants. While the possibility of an alternative learning tools fairly effective in teaching educational plant species is expressed by $72 \%$ of participants. Increased knowledge about the potential grounds evocative by $82 \%$ of participants. In the use of recycled materials as an alternative to green areas attracted $78 \%$ of the participants while almost $90 \%$ of participants keen interest in using hydroponic as a means of increasing economic activity and revenue. This training has also increased insight into the science of hydroponic vegetable that is expressed by $86 \%$ of participants(Graph.1).
Graph 1. Results of hydroponic system knowledge training

WORKSHOP HIDROPONIK

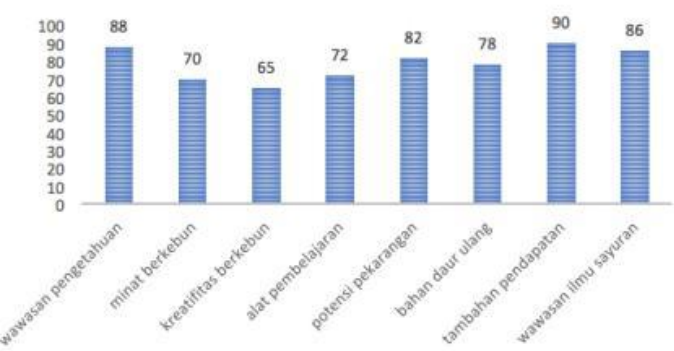

source: analysis, 2018

The results of the training as a whole is able to arouse the interest and capacity of understanding about hydroponic emphasis on the insight, the potential of the home yard as part of urban green space, vegetable science insights and increased revenue opportunities with the hydroponic system.

The simulation results manufacture hydroponic systems that do show an increase in the speed of participant's skills in less than half an hour to install as many by $88 \%$ of participants. Utilization of recycled materials as an alternative materials preferred by $70 \%$ of participants. Independence of the participants indicated by $65 \%$ of participants in the process of making hydroponic system. Participants are taught the skills assessment of the potential of the yard and city parks as a part of urban green space preferred by $72 \%$ of participants. While $82 \%$ interest in hydroponic carpentry skills actually show quite well. Some $78 \%$ of participants are interested in the possible results of the hydroponic system plants widely marketed. Almost all interested participants to attend their advanced training on advanced hydroponic systems equipped with the manufacture of small-scale green house that is $88 \%$ of participants(Graph.2). 
Graph 2. The simulation results manufacture hydroponic system

\section{SIMULASI HIDROPONIK}

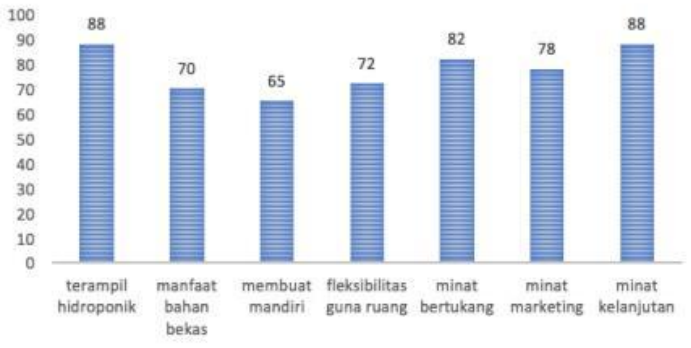

source: analysis, 2018

The results of the simulation of the manufacture of hydroponic as a whole show that mastery of skills of participants increased in the process of making the hydroponic system, increased interest in carpentry for manufacturing variations in models of hydroponic in accordance with the the shape of home yard (Fig.8), as well as the opening of insight to improve skills in the manufacture of advanced hydroponic systems equipped with the manufacture of small-scale green house(Fig.9).

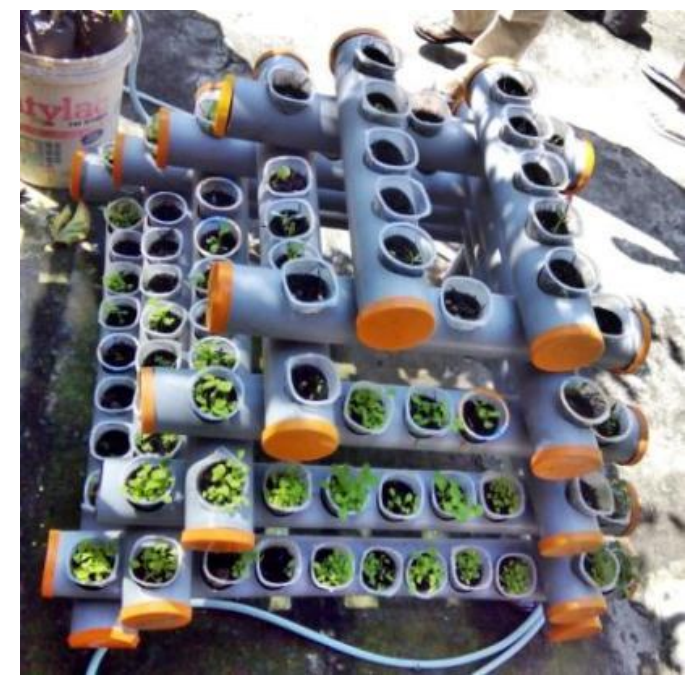

Figure 8. Alternative models of hydroponic system (source: Hulfa T, 2017[10])

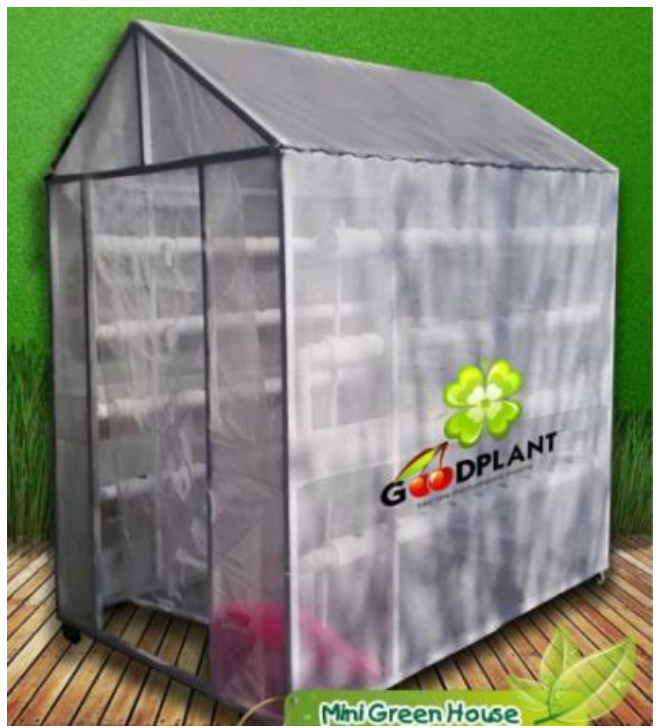

Figure 9. Small scale green house for hydroponic system (source: GOODPLANT, 2017[11])

\section{CONCLUSION}

This hydroponic making training activities have provided results that is able to arouse the interest and capacity of understanding about hydroponic as an alternative to the urban farming with emphasis on the insight, the potential of the home yard as part of urban green space, vegetable science insights and increased revenue opportunities with the hydroponic systems.

Simulation practice of making hydroponic provides improved skill mastery hydroponic model manufacturing process, increased interest in carpentry for manufacturing variations hydroponic models conform to the shape of home yard, as well as increasing interest in the manufacture of advanced hydroponic systems equipped with the manufacture of small-scale green house.

The use of hydroponic is most appropriate for urban settlements to improve urban green 
Harisdani, DD. et al. Hydroponic Training As An Alternative Urban Farming.

space and promote alternative urban farming for increase economic revenue[12].

\section{ACKNOWLEDGEMENT}

This community service supported by Universitas Sumatera Utara through Lembaga Pengabdian Masyarakat, which provides funding of community service program, which is titled Pelatihan Pembuatan Taman Kota Hidroponik di Kelurahan Tanjung Rejo, Medan. In accordance with the Letter of Assignment Agreement, NON PNBP Fiscal Year 2018 No. 172 / UN5.2.3.2.1 / PPM / 2018, April 16, 2018.

\section{REFERENCES}

[1] Lindarto, D. (2017). The Determinant Factors of Regional Development Toward Land Use Change in Deli Serdang. In IOP Conference Series: Materials Science and Engineering(Vol. 180, No. 1, p. 012280). IOP Publishing.

[2] Samsoedin, I (2009). Rencana penelitian integrative (RPI) tahun anggaran 2010-2014; Pengembangan hutan kota/lansekap perkotaan. Bogor: Pusat Penelitian Sosial Ekonomi dan Kebijakan (unpublished).

[3] Dirjentaru (2008). Peraturan Menteri Pekerjaan Umum Nomor: 05/PRT/M/2008 tentang Pedoman Penyediaan dan Pemanfaatan Ruang Terbuka Hijau di Kawasan Perkotaan. Departemen Pekerjaan Umum.

[4] Baxter, Diana (1984). Health in the Urban Environment; Health Status Indicators in Their Use in Measuring Quality of Life, in Urbanization and Ecodevelopment, with Special Reference to Kuala Lumpur. Edited by Yip Yat Hoong, Low Kwai Sim. Institut Pengajian Tinggi. Universiti Malaysia.

[5] Raffar, K.A. (1990). Hydroponics in tropical. International Seminar on Hydroponic Culture of High Value Crops in the Tropics in Malaysia, November. 25-27

[6] Badan Pusat Statistik Kota Medan (2016). Kota Medan Dalam Angka 2016. Badan Pusat Statistik, Kota Medan.

[7] Fukuyama, Francis (1999). Social Capital and Civil Society.The Institute of Publi Policy. George Mason University.

[8] Harisdani, D. D., \& Lindarto, D. (2018). PARTISIPASI MASYARAKAT DALAM PENGGUNAAN TEKNIK BIOPORI UNTUK MENGENDALIKAN BANJIR KOTA (Studi Kasus: Kelurahan Tanjung Rejo-Medan). NALARs, 17(2), 97-104.

[9] Setyabudi, R Nailufar (2017). Konsep Taman Edukasi pada Sekolah Dasar di Kota Malang (Studi kasus : SDN Lowokwaru 3 Malang). Jurnal RUAS, 15 (1).

[10] Hulfa, Trias (2017). Mengintip Hijaunya Kampung 3G (Glintung Go Green), Malang. Accessed from: http://blog.ub.ac.id/triasmariyahulfablog/2017/ 01/, viewed 01/09/2018

[11] GOODPLANT (2017). Green House Mini, Sistem Hidroponik. Accessed from: https://goodplant.co.id/green-house-mini/, viewed 03/09/2018

[12] Junainah, W., Kanto, S., \& Soenyono, S. (2016). Program Urban Farming Sebagai Model Penanggulangan Kemiskinan Masyarakat Perkotaan (Studi Kasus di Kelompok Tani Kelurahan Keputih Kecamatan Sukolilo Kota Surabaya). WACANA, Jurnal Sosial dan Humaniora, 19(3). 